Florida International University FIU Digital Commons

\title{
Examining How Wi-Fi Affects Customers Loyalty at Different Restaurants: An Examination from South Korea
}

Jiyeon Jeon

Florida International University, jjeon005@fiu.edu

DOI: $10.25148 /$ etd.FIDC000081

Follow this and additional works at: https://digitalcommons.fiu.edu/etd

Part of the Food and Beverage Management Commons

\section{Recommended Citation}

Jeon, Jiyeon, "Examining How Wi-Fi Affects Customers Loyalty at Different Restaurants: An Examination from South Korea" (2015). FIU Electronic Theses and Dissertations. 2218.

https://digitalcommons.fiu.edu/etd/2218 


\section{FLORIDA INTERNATIONAL UNIVERSITY}

Miami, Florida

EXAMINING HOW WI-FI AFFECTS CUSTOMERS' LOYALTY AT DIFFERENT

RESTAURANTS: AN EXAMINATION FROM SOUTH KOREA

A thesis submitted in partial fulfillment of the

requirements for the degree of

MASTER OF SCIENCE

in

HOSPITALITY MANAGEMENT

by

Jiyeon Jeon

2015 
To: Dean Mike Hampton

School of Hospitality and Tourism Management

This thesis, written by Jiyeon Jeon, and entitled, Examining How Wi-Fi Affects

Customers' Loyalty at a Different Restaurant, is referred to you for judgment.

We have read this thesis and recommend that it be approved.

Myongjee Yoo

Miranda Kitterlin

Lusby Carolin, Major Professor

Date of Defense: May 26, 2015

The thesis of Jiyeon Jeon is approved.

Dean Mike Hampton

School of Hospitality and Tourism Management

Dean Lakshmi N. Reddi

University Graduate School

Florida International University, 2015 
C Copyright 2015 by Jiyeon Jeon

All rights reserved. 


\section{DEDICATION}

It would have been impossible to finish my thesis without my committee members, friends, and family. I appreciate their support. 


\section{ACKNOWLEDGMENTS}

It would have been impossible to complete my thesis if my committee members had not supported me. Dr. Carolin Lusby helped me to process thesis and her guidance touched many facets of my thesis. Not only did Dr. Luisby serve as my committee chair, but also she gave me to adjust to my graduate school life.

My committee members have also supported me with their valuable time and efforts. To Dr. Yoo, she supported me with statistics and analysis as random sampling. Dr. Yoo, she helped me set up the idea of customer loyalty. To Dr. Kitterlin, your willingness to help students with warm words of encourage always impressed me. Thank you for your knowledgeable guidance and for serving on my committee.

I appreciate my parents' and my older sister's help. My family has always prayed for me and supported me with their best wishes. Finally, I would like to thank God most of all. 
ABSTRACT OF THE THESIS

EXAMINING HOW WI-FI AFFECTS CUSTOMERS' LOYALTY AT A DIFFERENT

RESTAURANT

\author{
by
}

Jiyeon Jeon

Florida International University, 2015

Miami, Florida

Professor Lusby Carolin, Major Professor

The main research objective of this study was to determine whether Wi-Fi affects customer's loyalty and how its impact differs depending on the type of restaurants. For the study I designed a primary field survey to collect data and performed multiple linear regression analysis to test the study hypotheses.

Findings show that Wi-Fi service factors turned out to be significant for all types of restaurants for both attitudinal and behavioral loyalty. However, not all of the Wi-Fi usage factors were significant consistently. Findings are expected to assist hospitality marketers to utilize Wi-Fi service as a point of service towards their customers.

Keywords: Attitudinal loyalty, Behavioral loyalty, Customer loyalty, Restaurant industry, Wi-Fi service. 


\section{TABLE OF CONTENTS}

CHAPTER

PAGE

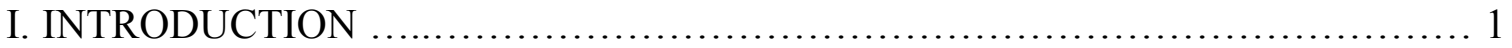

Problem Statement.......................................................... 3

Statement of Purpose.....................................................4

Significance of Study and Justification.................................... 4

Research Question................................................... 5

Definitions of Terms.......................................................

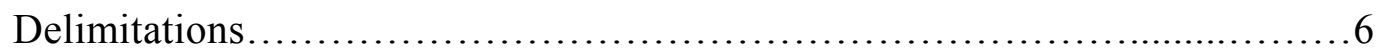

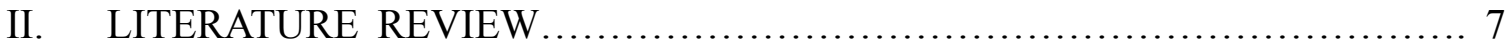

Customer Loyalty................................................... 7

Customer Loyalty ........................................ 7

Influential Factors on Customer Loyalty............................. 9

Measuring Customer Loyalty...................................12

The Development of Wi-Fi and its Utilization........................... 14

The Development of Wi-Fi.....................................14

Service Model of Wi-Fi........................................... 15

Wi-Fi as Hotspots............................................ 16

Influential Factors of Wi-Fi Usage..............................16

III.METHODOLOGY ................................................. 19

Research Hypotheses and Study Model..................................... 19

Instrument and Data Measurement........................................20

Data Collection and Sampling..........................................21

Data Analysis Method.................................................21

IV. RESULTS ....................................................... 23

Sample Profile.....................................................23

Testing of Hypotheses............................................... 25

Multiple Regression Analysis...................................26

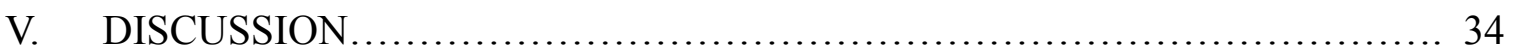

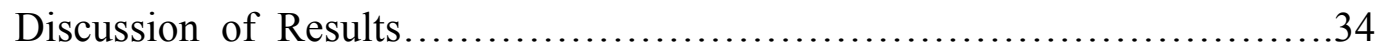

Implications for Management.......................................... 36

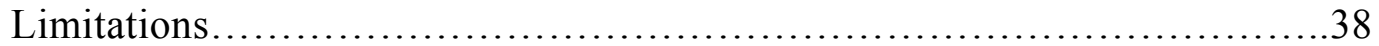

Recommendations for Future Research................................... 38

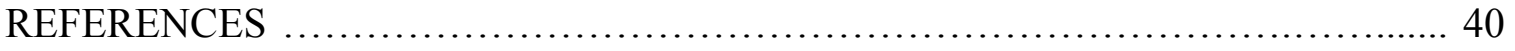

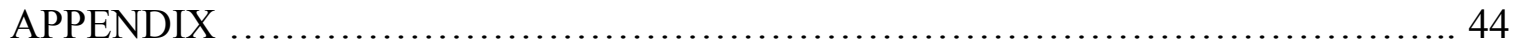




\section{LIST OF TABLES}

TABLE

PAGE

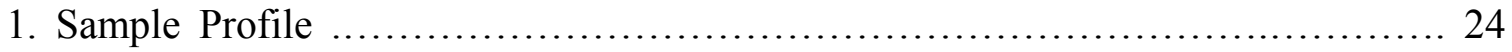

2. Summary of Regression Analysis for Coffee Shop Attitudinal Loyalty................26

3. Significance of Regression Coefficients........................................26

4. Summary of Regression Analysis for Coffee Shop Behavioral Loyalty...............27

5. Significance of Regression Coefficient....................................27

6. Summary of Regression Analysis for Fast-Food Attitudinal Loyalty................ 28

7. Significance of Regression Coefficient..................................... 29

8. Summary of Regression Analysis for Fast-Food Behavioral Loyalty.............. 30

9. Significance of Regression Coefficient........................................ 30

10. Summary of Regression Analysis for Casual-dining Attitudinal Loyalty............. 31

11. Significance of Regression Coefficient..................................... 31

12. Summary of Regression Analysis for Casual-dining Behavioral Loyalty............. 32

13. Significance of Regression Coefficient......................................... 33 


\section{CHAPTER I}

\section{INTRODUCTION}

Wireless Fidelity Networks "Wi-Fi" technology is a growing source of revenue

in the market today. Wi-Fi is unique in that it constantly offers customers secure, wireless, and mobile access to the internet (Smithers, 2007). Wi-Fi provides access to technology, which has moved from being a customer's luxury to a daily necessity (Berezina, Bilgihan, Cobanoglu, \& Nusair, 2012). In general, wireless networks can be used everywhere and any standard Wi-Fi device works anywhere in the world thus its usage has become closely related to our daily lives nowadays (Berezina, et al, 2012; Hassine, 2006).

Restaurant businesses in the hospitality industry have been struggling to improve various types of services or rewards because competition has been constantly increasing. As a result, restaurants attempt to provide a variety of service, such as loyalty programs and mobile applications so they can increase customer's satisfaction and loyalty (Jang \& Mattila, 2005). Alongside these various types of service, Wi-Fi service can also be used as tool to compete with others (Yusio \& Tiong, 2011).

Due to Wi-Fi's popularity and familiarity with consumers, businesses in the hospitality industry have been opening up to provide Wi-Fi as a new service for customers (Berezina, et al, 2012). Recently, hotels started to provide free Wi-Fi as a value added service for their visitors. By giving free Wi-Fi service without any contract, hotels are enhancing guest experience as customers can be more productive and stay better connected to their friends or family. For example, Hyatt Hotels offer free Wi-Fi service for every guest. They provide premium Wi-Fi service (higher-speed) for all of the 
members of their loyalty program and provide general Wi-Fi service to non-member customers (Danny, 2015).

Generally, hotels are known to have greater quality service and higher standards of customer care compared to restaurants. Compared to previous years, more hotels are offering free Wi-Fi as of 2015. Wi-Fi has been seen as the most essential factor as an amenity when guests stay at hotels. Wi-Fi is also a significant factor that is considered when consumers book hotels. By offering free Wi-Fi service, hotels have been able to increase customers satisfaction levels. As a result, the level of customer loyalty is usually higher in hotels than restaurants (Danny, 2015).

Nowadays, consumers can also use Wi-Fi service on airplanes as a number of airlines are providing Wi-Fi service. Consumers want to use their mobile devices in-flight, and continue using Wi-Fi service for other devices. Thus, airline companies are trying to improve the speed and availability of Wi-Fi in flight because demand is increasing (Rice, 2013).

Likewise, the more variety of services restaurants and coffee shops offer, the stronger loyalty they are able to create (Jang \& Mattila, 2005). Offering Wi-Fi has become a means of increasing customer loyalty at restaurants. Specifically, the pressure has trickled down to restaurants as customers' demand Wi-Fi is increasing. Restaurant customers indicated Wi-Fi as an important reason for their repeat visit and purchase intention. For example, all else being equal between two restaurants, if the restaurant provides Wi-Fi service for their visitors, consumers will prefer to revisit the restaurant offering Wi-Fi service. Wi-Fi Internet service can be an advantageous tool for restaurants to attract new consumers and hold customer loyalty (Berezina, et al, 2012). 
Additionally, restaurants are more likely to generate higher revenues when customers spend more time at the restaurants. Wi-Fi has been found to act as a tool to encourage consumers to stay longer at restaurants (Natasa, 2014). Thus, it has been suggested that restaurants may build stronger loyalty than before by providing free $\mathrm{Wi}-\mathrm{Fi}$ service for customers (Berezina, et al, 2012).

Starbucks changed Wi-Fi service to a free model. The Rose Group set up the WiFi service as two hours of free use. Panera provides unlimited free Wi-Fi service for their consumers, although consumers cannot use unlimited free Wi-Fi when they visit during peak lunch hours.

Moreover, Sammy's Wood Fired Pizza also offers limited free Wi-Fi service for one hour to their consumers. Consumers have to pay money if they want to use more WiFi after an hour (Natasa, 2014). Numerous restaurants and coffee shops are offering WiFi service to attract consumers because Wi-Fi is in high demand in restaurants. Furthermore, the cost to offer Wireless Fidelity Networks is not expensive and is easy to set up at any Location. Wi-Fi service availability outweighs other in consumer loyalty (Berezina et al., 2012).

\section{Problem Statement}

Technology has become one of the most important competitive advantages for hospitality companies (Buhalis, 1998). Consumers have started to demand Wi-Fi service in restaurants ,many restaurants are already providing Wi-Fi to their guests. In response to the demand, restaurants and cafes have started to consider Wi-Fi service as an essential amenity. Several studies show that tourism destinations can make more revenue by providing Wi-Fi service in public places and tourist attractions for travelers (Berezina et 
al., 2012). It has become vital for restaurants to understand the impact of Wi-Fi due to its high demand and outcome.

However, there are a limited number of scientific and empirical studies on examining effect of the availability of Wi-Fi on restaurant customer loyalty. In fact, there is a limited amount of studies that investigate restaurant services related to $\mathrm{Wi}-\mathrm{Fi}$ as a whole. Additionally, there is a need for research in the international market because restaurant businesses have already become part of the global market. The more restaurants become a market, the more technology such as Wi-Fi becomes demand (Natasa, 2014).

\section{Statement of Purpose}

The purpose of this study is to explore the impact of Wi-Fi service on customer's loyalty behavior to a specific restaurant in South Korea. Additionally, this study examined whether Wi-Fi service has an impact on different types of restaurants (coffee shops, fast-food, casual-dining restaurants). Existing research content offers that restaurants can build up stronger loyalty if they provide special service for customers (Berry, Parasuraman, \& Zeithaml, 1991; Bowen \& Chen 2001). Fast-food and casualdining restaurant consumers often pursue rewards as an entertainment factor. There are various advantages of wireless connectivity in restaurants. In order to hold current

consumers and attract new consumers, it is important to grasp the effect of Wi-Fi service in restaurants on customers' returning (Berezina et al., 2012)

\section{Significance of Study and Justification}

This study will be useful in understanding the impact of Wi-Fi service and will shed light on cross cultural statistical impact in customer loyalty. 
This study estimated the potential of Wi-Fi service to be an effective tool to build relationships with customers and increase customer loyalty for restaurants. Wi-Fi service has shown to have significant effect on attracting customers to return to restaurants (Berezina et al., 2012). Thus, Wi-Fi service may help restaurant operators establish effective operations and marketing strategies for maximum customers retention. This study expected to provide new insights into customers' value proposition in regards to Wi-Fi for the restaurant industry. It provides significant information that can help restaurants and coffee shops to manage their businesses by effectively utilizing Wi-Fi as a service and understanding how it may affect customer loyalty.

\section{Research Question}

The research questions addressed in this study are as follows:

1. Is there an impact of Wi-Fi service on customer loyalty at restaurants in South Korea?

2. Is there a difference in the significance of Wi-Fi service factors among different type of restaurants in South Korea?

\section{Definitions of Terms}

Throughout the current study, the following terms are used for the purpose of conceptualizing Wi-Fi and defining customer loyalty.

Secure: It offers data privacy to network users and protects the network against malicious use (Balachandran, Voelker, \&Bahl, 2005)

Wi-Fi: Wireless networking technologies.

TAM model: The technology acceptance model is a model for user acceptance of information system (Davis, Bagozzi, \&Warshaw, 1989). 
Loyalty: A deeply held commitment to revisit or repurchase a preferred product (Oliver, 1997).

Loyalty Phases: Loyalty phases include cognitive, affective, conative and action loyalty (Oliver, 1999).

\section{Delimitations}

Time and location to collect data were delimitations of this study. This study collected data during a one-month period, starting on February 26, 2015, to March 25, 2015, in Busan Korea. The data collection for this study concentrated on three types of restaurants: coffee shops, fast-food restaurants, and casual restaurants. The survey was conducted in Korean. This study used a non-probability convenience sampling method to collect data. 


\section{CHAPTER II \\ LITERATURE REVIEW}

\section{Introduction}

The objective of this chapter is to better understand the concepts underlying customer loyalty and development of Wi-Fi. The literature review is separated into two different sections. The first section reviews customer loyalty, influential factors on customer loyalty, and measuring customer loyalty. The second section describes the development of Wi-Fi and its utilization. It reviews the development of Wi-Fi, service model of Wi-Fi, Wi-Fi as hotspots, and influential factors of Wi-Fi usage.

\section{Customer Loyalty}

\section{Customer Loyalty}

Loyalty is a deeply held commitment to revisit or repurchase a preferred product and service in the future despite situational influences. In the past, hospitality firms focused on attracting new customers rather than existing customers. Nevertheless, a lot of companies prefer to hold their existing customers. That is because firms created a number of new customers, it does not necessarily mean that they are able to increase a significant amount of profit and maintain profit from new customers (Bolton, 1998). It is more beneficial to hospitality firms to increase profit. Thus, hospitality firms realized that gaining customers in the current economy will be difficult, so companies have concentrated on keeping those they already have (Bolton, 1998). So as to achieve profitable growth, some companies are continuing to focus on their most profitable customers, channels, and products (Kotler \& Keller, 2011). According to Oliver (1997), 
consumers often prefer to buy the same-brand or same brand-set purchasing when they become loyal.

Oliver (1999) indicates a four-stage loyalty model composed largely of affect, action, intention, and belief. The first loyalty stage is cognitive loyalty. At this phase, customers make decisions from information, such as price, quality and so on. Cognitive loyalty is the weakest type compared to other stages of loyalty because consumers can easily switch to other alternatives when they offer better prices or benefits. Providing relativity to price is the most important aspect of cognitive loyalty and it is only based on brand belief (Oliver, 1999).

The second loyalty phase relates the favorable behavior to a specific brand and product. For example, customers can build affective loyalty through a satisfying shopping experience. Nevertheless, just because companies build up loyalty for their customers does not necessarily mean that it will be maintained. Consumers are able to change their mind if there are competitive offerings. Affective loyalty is decreased when competitors provide better service for consumers (Oliver, 1999).

Conative loyalty can be created by repeat purchase and positive experiences. Although conative loyalty is much stronger than affective loyalty, it also has a vulnerable point, as it may repeat the same mistakes. The factor in diminishing conative loyalty is that it is not until consumers have developed the decision to avoid factors of alternative offerings that they can be conatively loyal. Hence, it is able to become strong after consumers experience a positive effect towards the brand (Oliver, 1999).

Lastly, the strongest phase of loyalty is action loyalty. It is based on cognitive, affective, and conative loyalty towards the brand, and indicates that consumers will 
purchase from the same brand even if other competitors offer better deals (Oliver, 1999).

Just because competitors provide better options for consumers, it does not necessarily mean that they will think about considering alternatives.

\section{Influential Factors on Customer Loyalty}

Restaurants put a premium on customer loyalty to generate profit since loyalty has become a significant foundation (Han, Back, \& Barrett, 2009). Restaurants spend much more money attracting new customers than retaining existing customers. The total cost increases five to six times to attract new customers compared to attracting existing customers (Brodie, Davis, Lindgreen, \& Oliver, 2000). There are various kinds of factors that impact restaurant customers' loyalty. Moreover, influential factors will be different depending on the type of restaurant (Jang \& Mattila, 2005).

According to Oliver (1999), there are two groups to exert strong influence on loyalty: personal and situational characteristics. Personal characteristics will be general moderators in the four-stage loyalty model and have an effect on each link in the model (Evanschitzky \& Wunderlich, 2006).

The first personal characteristic is age. Generally, older consumers do not tend to search for information about new products (Raphaelle, Gilles, \& Eric, 2005). Younger consumers usually prefer to seek alternative information that can influence their loyalty behavior. Nevertheless, older consumers are more prudent in purchasing, since they rely more on fewer decision criteria. They are going to rebuy through their personal experience. Thus, companies are able to build up stronger loyalty between older consumers compared to younger consumers (Evanschitzky \& Wunderlich, 2006). According to Homburg and Giering (2001), age affects the four loyalty steps not only 
because there is a close correlation between satisfaction and loyalty, but also because age has various factors.

Gender has a direct effect on outcome and variables about loyalty (Birgelen, Odekerken, Lemmink, Ruyer, \& Wetzels, 2000). Gender plays an important role as a moderator variable in marketing strategies, and as it relates to social behaviors. Typically, males easily tend to switch to an attractive deal more often than females (Gill \& Saad, 2000). That is, by changing their satisfaction levels, men do not prefer to remain loyal.

Education is linked stronger to less-educated consumers than well-educated consumers (Evanschitzky \& Wunderlich, 2006). In making decisions, people with a higher level of education often try to obtain more information. By coming up with some new information, they feel more comfortable. In comparison with higher levels of education, people who have a lower level of education do not want a lot of information when they buy new products (Homburg \& Giering, 2001). The reason for this is that lesseducated consumers do not rely on information when buying products, and the satisfaction is more important than gathering good information. Thus, consumers with a higher level of education switch to alternatives easier than those with less-education.

Income is similar to education. Normally, well-educated consumers have more opportunities to earn a higher income than less-educated consumers. Thus, higher income consumers are more likely to seek alternative information and switch if competitors offer attractive deals (Evanschitzky \& Wunderlich, 2006). Lower income consumers tend to show stronger loyalty based on the satisfaction from their previous experience and it is harder to change their opinions. 
The first situational characteristic is expertise. Expert consumers have extensive knowledge about a product and alternative choices (Busler \& Till, 2000). Hence, they will be able to become more susceptible to the competitive offerings than others (Dacin $\&$ Mitchell, 1996). On the other hand, less experienced consumers tend to rely on their evaluation that they would build on past experiences.

Price orientation is another form of motivation. Price oriented consumers usually search for better deals, and they are fully aware of offerings with competitors. Just because price oriented consumers have had a pleasurable experience from a specific brand, it does not necessarily mean that they will become loyal. This type of customer feels satisfied by searching for better deals (Arnold \& Reynolds, 2003). However, less price-oriented consumers do not like to search for bargains. They usually create loyalty through their past experiences with the service provider.

Critical incident recovery has a close correlation between service and marketing (Birgelen et al., 2001). A critical incident can suddenly occur where the customer says that the service is not good enough and needs to be improved. In order to recover from a negative incident, service providers must make an effort for consumers who had a negative experience to be fully satisfied.

External factors involve many types of facts, such as switching costs and situational factors. The most important things as to external factors are the switching costs because those can present serious risks to companies (Heide \& Weiss, 1995). That is, not only can consumers easily switch to other alternatives depending on the costs, but also companies hold their consumers by keeping high switching costs. Higher switching costs of companies to maintain their consumers stronger leads to switching costs of 
companies that increase behavioral loyalty (Porter, 1985). In other words, customer loyalty will be decreased if switching costs are low. For instance, "the costs in time and effort of changing this casino to another one are high for me. It would be very inconvenient for me to go to other casinos" (Baloglu, 2002, p. 51).

There are various kinds of situational factors and consumers often tend to purchase based on situational factors, such as physical, social surroundings, temporal perspective, task definition, and antecedent states (Belk, 1975). Those five factors play significant roles when and why consumers make a purchase. Physical surroundings are the most suitable features of a situation. These surroundings are involved physical environment characteristics, such as geographical location, interior decoration, sounds, the beauty of the scenery, lighting, and weather. Customers are usually influenced by consumer behavior in social surroundings because not only will other consumers be able to affect a customer's purchasing behavior, but also consumers tend to follow groups that are relevant to them. Temporal perspective identifies situation from the time of day to season of the year. Additionally, it can be measured in the past or future event. Task definition is particularly relevant to obtain information as to products and select shops to buy specific purchases. Moreover, it may indicate other buyer and user roles as the individual. The last one is antecedent states. These are involved transient moods, such as concern, happiness, antagonism, and excitement instead of the chronic feature (Belk, 1975).

\section{Measuring Customer Loyalty}

According to Jacoby and Chestnut (1978), there are three types of approaches to measuring loyalty: the behavioral approach, the attitudinal approach, and the composite 
approach. The behavioral approach based on the consumers' actual purchasing behavior. Consumers who are behaviorally loyal usually prefer to buy the same brand and do not choose alternatives. Thus, it is involved with high consumers repurchase intentions. Repurchase intention indicates the consumer's intention to buy the product or service over and over (Petrick, 2005). Additionally, consumers who are behaviorally loyal are likely to pay more for the service or product. Thus, willingness to pay more can be used to measure behavioral loyalty (Wicker, 1969).

Word of mouth refers to the recommendation and it is also known as voluntary partnerships, which are often suggested as behavioral outcomes of loyalty. Word-ofmouth recommendations include promoting the company, making positive comments, and business referrals (Baloglu, 2002). More customers have satisfaction in the restaurants and, restaurants can maintain a strong relationship with their customers (Park \& Jang, 2014).

The attitudinal approach measures loyalty based on the favorable attitude towards the brand (Backman, 1988). Attitudinal definitions of consumer loyalty base intensity of loyalty on consumers' preferences, intentions or strength of affection for a brand (Olson \& Jacoby, 1971). Attitudinal loyalty is strongly associated with the consumers' satisfaction with products and service (Kumar, Shah, \& Venkatesan, 2006). Attitudinal loyalty will not directly create profit because it does not cause customers to make the actual purchase. However, companies are able to build up positive images from attitudinal loyalty (Cheng, 2011). Other important antecedents may include trust, emotional and psychological attachment. Trust is an important factor to measure for attitudinal loyalty because it is involved in building a relationship with the company. 
When companies provide consistent service, consumers build trust towards the brand (Morgan \& Hunt, 1994). Emotional commitment can create a good brand image because it makes consumers have a sense of belonging to the company. By making consumers feel good and providing hedonic value, companies can build up emotional commitment, and these values can deliver consistent and friendly service (Bolaglu, 2002).

Behavioral measures overestimate true loyalty, as they do not account for consumers that were spuriously loyal (Day, 1969). Moreover, consumers should hold a favorable attitude to the specific brand and products in order for consumer to become truly loyal. Thus, the composite approach is based on integrating the behavioral and attitudinal measures (Baloglu, 2002).

\section{The Development of Wi-Fi and its Utilization}

\section{The Development of Wi-Fi}

Wireless technologies are not any more likely to have attracting people due to the number of people who are using mobile devices, which is increasing rapidly. Hence, WiFi has been used in many places to provide access to the Internet and is developing from day to day (Ramirez, 2010). Wi-Fi has been developing a model, and there are various wireless communication technologies, such as IEEE 802.11, 803.11, 3G, 4G, 5G and Long Term Evolution (LTE) (Ullah, 2012).

Nowadays, Wi-Fi is not expensive technology and it is easy to set up the Wi-Fi service in the public area because there are a lot of companies that provide Wi-Fi service to cafes, hotels, and public places. Wi-Fi technology can be easily set up in offices, airports, markets and other any locations, and it can provide advantages in mobility, ease of use and low cost. Thus, demand in Wi-Fi has become more important in business and 
everyday-life and most people are able to connect to Wi-Fi service at public places, such as shopping malls, hotels, airports and restaurants (Ullah, 2012). Wireless networking technologies (Wi-Fi) can be divided in to three types and one is wired connection to a broadband provider, and access point, and a computer connected by wired and wireless connections (Ullah, 2012).

\section{Service Model of Wi-Fi}

Wi-Fi. Wi-Fi technology connects devices together without wires. Wi-Fi technology is based on IEEE 802,11 and has developed as various types of technology, such as IEEE 802.11, IEEE 803.11, 3G,4G, WiMax, LTE, and 5G. Wi-Fi offers different speed and quality depending on types (Bradwell, 2005).

The IEEE 802.11 was the initial model of wireless technology and was developed to IEE 803.11. Next, 3G is third generation mobile communication. It is commonly used as a mobile phone standard for transferring data. It includes different features like transfer of enhanced multimedia, such as voice, videos, data, cellular telephone, web browsing, email and so on (Ullah, 2012).

The fourth generation $(4 \mathrm{G})$ mobile communication is a development of the voice and data transfer communication technology approaches and standards from third generation mobile communication. It provides mobile ultra-broadband internet access for mobile devices, such as laptops, smart-phones, and so on. Moreover, 4G supports applications, such as mobile banking, peer to peer networking, usage of internet services, and more. Nowadays, two types of $4 \mathrm{G}$ network are commercially deployed, which are WiMax and Long Term Evolution (LTE). WiMax stands for Worldwide Interoperability for Microwave Access. WiMax offers flexibility in terms of deployment options and 
services. LTE is long term evolution technology, and it is the newest standard for mobile wireless communications up to date, as of 2015. It offers broadband access for fixed, portable and mobile devices. The benefits of LTE technology include increased capacity, reduced network complexity, latency, improved coverage, lowered deployment and operational cost (Ullah, 2012).

The fifth generation (5G) of mobile communications technology is being proposed as a standard for the next phase of mobile telecommunication. Compared to 4G, 5G can provide higher speed and wider area than 4G. It is the most important benefit of 5G. The 5G technology will be capable of supporting wireless world wide web and will support it by allowing highly flexible networks. In the revolutionary view 5G technology will be able to interconnect with the world without any limits (Ullah, 2012).

Wi-Fi as Hotspots. Hotspots often operate Wi-Fi technology through a router, providing Internet access. Free hotspots usually provide free access to menus or purchase lists through payment systems like PayPal, or credit cards (Ullah, 2012). The disadvantage about Wi-Fi as a hotspot refers to a malicious individual who sniffs the data sent by a user on a free hot spot including deciphering passwords, and login names (Ullah, 2012). There are some safety tips for using public Wi-Fi in secure ways including, using firewall, turning off wireless network when not in use, hiding important files, and not typing credit card numbers, passwords or significant data without proper safety mechanisms on browsers. While using Wi-Fi hotspots people should be sure that sent information must be fully encrypted, and always logout after finishing their work (Ullah, 2012). 


\section{Influential Factors of Wi-Fi usage}

There are a number of factors that influence the usage of Wi-Fi service. The technology acceptance model was designed based on users' acceptance behavior towards an information system (Davis, 1989;Davis, 2000). According to Davis (1989;2000), perceived usefulness and perceived ease of use are the two main factors that influence technology acceptance. Davis (1989) defined the meaning of perceived usefulness as "the degree to which a person believes that using a particular system would enhance his or her job performance and this follows from the definition of the word useful and capable of being used advantageously"(Davis, 1989, p. 320). By using the TAM system about usefulness, people indicate that it can be helpful to enhance their task or job performance since it can enable people to understand new systems (Davis, 2000). Moreover, not only do people prefer to use an application to do their work effectively, but also it is able to help them perform their job. Perceived usefulness gives some benefits to improve users work performance, so they believe that it can offer great value for their work (Davis, 1989). Perceived usefulness can de described by value, reliability, and continuity (Davis, 1989; Swanson, 1987).

Perceived ease of use is defined as "the degree to which a person believes that using a particular system would be free of effort and this follows from the definition of ease and freedom from difficulty or great effort'(Davis, 1989, p. 320). Perceived ease of use is a basic determinant as to user behavior because it is much more useful to use the easier system if other things are equal (Davis, 2000). Even if the program or technology may improve users' performance, they will not use it if it is difficult to use. Consequently, restaurants should offer Wi-Fi service that their consumers can easily use. Perceived ease 
of use is based on accessibility, convenience, ease of use, and availability (Davis, 1989; Swanson, 1987).

According to the Demarez, Evens, Schnurman and Yerleye (2010), speed and security are also imperative parts of using Wi-Fi service other than accessibility, ease of use, and continuity. Public networks are quite vulnerable and insecure in practical use. In public and crowded places, anyone can steal a password or important information as to personal information, credit cards, and more (Onguardonline, 2011). Thus, to maintain customers' utilization of a location's Wi-Fi, it is crucial that restaurants provide protection against potential security threats before installing Wi-Fi service (Means, 2013). There are numerous types of companies that provide Wi-Fi security programs for restaurants; they can protect any identity of other customers online (Dicenzo, 2012). Thus, restaurants are able to entrust protecting security (Means, 2013). According to Demarez et al., (2010), customers also perceived speed to be a critical factor in using Wi-Fi service. Additionally, Berezina et al. (2012) suggested the importance of cost and safety of using Wi-Fi service.

\section{Summary}

This chapter reviewed two important concepts in the study. The first concept is about customer loyalty, influential factors on customer loyalty and measuring customer loyalty. The second concepts are about the development of Wi-Fi, service model of Wi-Fi, Wi-Fi as hotspots and influential factors of Wi-Fi usage.

Customer loyalty is an important point in the hospitality industry because loyalty is a deeply held commitment to repurchase products and services in the future despite situational influences. 


\section{CHAPTER III}

\section{METHODOLOGY}

\section{Introduction}

This chapter focuses on the research methods used to test the study hypotheses. The study hypotheses, the measurement method and scales, sample and data collection methods, and the data analysis process are discussed in the following section.

\section{Research Hypotheses and Study Model}

The findings of the literature review suggested that there is an impact of Wi-Fi service on customer's return to a restaurant. Thus, this study suggests a positive relationship between Wi-Fi service usage and restaurant loyalty. This study researched loyalty in terms of behavioral loyalty and attitudinal loyalty. Additionally, this study selected three different types of restaurants (coffee shops, fast-food restaurants, casualdining restaurants) to investigate how the Wi-Fi service differs depending on the operation type. Overall, the following study hypotheses were derived:

H1: Wi-Fi service will have a positive impact on coffee shop loyalty.

H1a: Wi-Fi service will have a positive impact on coffee shop attitudinal loyalty.

H1b: Wi-Fi service will have a positive impact on coffee shop behavioral loyalty.

H2: Wi-Fi service will have a positive impact on fast-food restaurants' loyalty.

H2a: Wi-Fi service will have a positive impact on fast-food restaurants' attitudinal loyalty.

H2b: Wi-Fi service will have a positive impact on fast-food restaurants' behavioral loyalty. 
H3: Wi-Fi service will have a positive impact on casual-dining restaurants' loyalty.

H3a: Wi-Fi service will have a positive impact on casual-dining restaurants' attitudinal loyalty.

H3: Wi-Fi service will have a positive impact on casual-dining restaurants' behavioral loyalty.

\section{Instrument and Data Measurement}

In order to test the hypotheses, this study designed and conducted a survey. The survey was developed as a self-administered instrument in three sections based on the literature review. The survey was translated in Korean by the researcher, and it was reviewed by two other faculty members to ensure validity. Additionally, a pilot test was conducted among twenty University students in Korea in order to establish content validity. After analyzing the returned questionnaires, minor revisions were made to the questions based on the suggestions from the participants of the pilot test.

Consequently, the survey was designed to measure customers' level of agreement using a seven-point scale, meaning 1 as "extremely low" to 7 as "extremely high". The first two sections were categorized into different types of restaurants: coffee shops, fastfood restaurants, and casual-dining restaurants.

The first section asked questions related to the respondents' opinion on the various aspects of Wi-Fi usage at different types of restaurants. Ten different items were used to measure Wi-Fi usage: "Wi-Fi service available," "Wi-Fi service value," “cost of Wi-Fi," "reliability of Wi-Fi," "speed of Wi-Fi," "safety of Wi-Fi," "accessibility of WiFi," "continuity of Wi-Fi," "ease of using Wi-Fi," "use of encryption while using Wi-Fi" 
(Berezina et al., 2012; Davis; 2000, Demarez et al., 2010). The second section asked questions related to attitudinal loyalty and behavioral loyalty. The attitudinal loyalty dimensions included "feel good," "provides hedonic value," "provides consistent service," and "satisfaction". The behavioral loyalty dimensions included "make a purchase," "revisit intention," "willingness to pay more," "recommendation," "maintain a relationship" (Baloglu, 2002; Petrick 2004). Attitudinal and behavioral loyalty was later created into one single variable by computing the mean scores. The last part of the survey consisted of demographic questions, such as age, educational, background, gender, and income.

\section{Data Collection and Sampling}

Prior to data collection, a protocol explaining the study was submitted to the Institutional Review Board (IRB) of Florida International University. Approval was granted by the IRB to conduct research involving human subjects. Data was collected from February 26, 2015 through March 25, 2015. This study used a convenience sampling method and distributed the questionnaires through online and offline channels in South Korea. A total number of 250 questionnaires were sent out by e-mails or text messages, embedding a link to the consent form to the potential participants. Another 250 questionnaires were distributed to students at Pohang University, Korea and at the Busan Food and Beverage Association. Overall, a total of 345 questionnaires were collected for this study. After deleting 31 invalid surveys, 314 responses were kept for further analysis.

\section{Data Analysis Method}

Data was entered into the Statistical Packages for Social Sciences (SPSS) 22.0 for Windows. Descriptive statistics such as frequencies and percentages were used to 
examine the respondents' individual demographic information. Multiple regression analysis was performed to investigate the impact of Wi-Fi service among coffee shops, fast-food restaurants, and casual-dining restaurants.

This study performed multiple regression analysis to indicate how Wi-Fi service affects customer's loyalty at different types of restaurants. Multiple regression is a "method of selecting variables for inclusion in the regression model that starts by selecting the best predictor of the dependent variable" (Hair, Anderon, Tatham \& Black, 1998, p. 147).

The assumptions that were needed to be checked before performing regression analysis were the followings: normality, independence of observations, linearity, constant variance, and multicollinearity. All data were screened for outliers and scatter plots were reviewed of nonlinear distributions and relationships (Hair, Anderon, Tatham, \& Black, 1998).

\section{Summary}

This study designed a questionnaire and conducted a survey to test the hypotheses. Three types of restaurants (coffee shops, fast-food restaurants and casual dining restaurants) were chosen. Wi-Fi service was selected as usage factors, and loyalty was examined from two different perspectives: attitudinal and behavioral. In order to indicate how Wi-Fi service affects customers' loyalty among the different types of restaurants, multiple regression analysis was conducted to test the study hypotheses. 


\section{CHAPTER IV}

\section{RESULTS}

\section{Introduction}

This chapter shows the data analysis and the results of this study. The demographic information of the participants is described in the first section. The results of the hypotheses tested used multiple linear regression analysis as the effect of Wi-Fi service on the different types of restaurants.

\section{Sample Profile}

A total of 345 questionnaires were collected for this study. After deleting 31 invalid surveys, 314 responses were kept for further analysis. Table 1 describes the sample profile for this study. About $42.7 \%$ of the respondents were male, and $57.3 \%$ were female. Nearly $9 \%$ of the participants had completed high school, $26.1 \%$ had an associate's degree, $52.2 \%$ had a bachelor's degree, $10.2 \%$ had earned a master's degree, and $2.2 \%$ had earned a doctoral degree. The marital status of the majority of the respondents was either single or married , and only one was divorced. For example, 69.1\% of the respondents were single, $30.6 \%$ were married and $0.3 \%$ was divorced. With regard to annual income, $47.8 \%$ of the respondents had an annual income of less than $\$ 10,000$. Approximately $5.7 \%$ had an annual income of $\$ 10,000$ to $\$ 19,999,22 \%$ had between $\$ 20,000$ and $\$ 29,999,10.8 \%$ had between $\$ 30,000$ and $\$ 39,999,5.4 \%$ had between $\$ 40,000$ and $\$ 49,999$, and $3.8 \%$ had between $\$ 50,000$ and $\$ 60,000$. Under $4.5 \%$ had an annual income of more than $\$ 70,000$. 
Table 1

Sample Profile

\begin{tabular}{lcr}
\hline Variables & Frequency & \multicolumn{2}{c}{ Valid \% } \\
\hline Gender & 180 & 57.3 \\
Male & 134 & 42.7 \\
Female & & \\
Education & 29 & 9.2 \\
High school & 82 & 26.1 \\
Associate's Degree & 164 & 52.2 \\
Bachelor's Degree & 32 & 10.2 \\
Master's Degree & 7 & 2.2 \\
Doctoral Degree & &
\end{tabular}

\section{Marital Status}

Married

Separated

Single

Age

18-24 years

25-34 years

35-44 years

45-54 years

55 or older

Annual Income

$\$ 10,000$ or less

$\$ 10,000$ - \$19,999

$\$ 20,000$ - \$29,999

$\$ 30,000$ - \$39,999

$\$ 40,000$ - \$49,999
150

96

105

100

54

42

13

30.6

0.3

69.1

33.4

31.8

17.2

13.4

4.1

47.8

18

5.7

69

22.0

34

10.8

17

5.4 
$\$ 50,000-\$ 60,000$

$\$ 70,000$ and over
12

14

314
100.0

\section{Testing of Hypotheses}

This study conducted multiple linear regression analysis to test the study hypotheses. Multiple linear regression analysis was performed with attitudinal loyalty and behavioral loyalty as the dependent variables and the Wi-Fi usage factors as the independent variables. The first hypothesis was formulated to find out the effect of Wi-Fi service on coffee shop restaurant's loyalty as following:

H1: Wi-Fi service will have a positive impact on coffee shop loyalty.

H1a: Wi-Fi service will have a positive impact on coffee shop attitudinal loyalty.

H1b: Wi-Fi service will have a positive impact on coffee shop behavioral loyalty.

As can be seen in table 2, the result for coffee shop attitudinal loyalty was significant since the sig. level is lower than the critical alpha level of 0.05 . Thus, H1a was supported and it can be concluded that there is a positive impact of Wi-Fi on coffee shops attitudinal loyalty. Approximately $35.5 \%$ of the coffee shop attitudinal loyalty was explained by the Wi-Fi usage factors from the regression model.

Nevertheless, not all Wi-Fi usage factors turned out to be significant. Table 3 shows that the results of each factors related to attitudinal loyalty separately. Only worth paying $(\mathrm{p}<0.05, \beta=.148, \mathrm{t}=3.44)$, safety $(\mathrm{p}<0.05, \beta=-.121, \mathrm{t}=-2.15)$, accessibility $(\mathrm{p}$ $<0.05, \beta=.133, \mathrm{t}=2.02)$ and encryption $(\mathrm{p}<0.05, \beta=.074, \mathrm{t}=2.08)$ turned out to be significant. 
Table 2

Summary of Regression Analysis for Coffee Shop Attitudinal Loyalty ( $N=314)$

\begin{tabular}{crrrr}
\hline $\mathrm{R}$ & $\mathrm{R}^{2}$ & Adjusted $\mathrm{R}$ & $\mathrm{F}$ & \multicolumn{2}{c}{ Sig. } \\
\hline 0.596 & & & & $0.00^{*}$ \\
\hline Note. ${ }^{*} \mathrm{p}<0.05$. & 0.355 & 0.334 & 16.671 &
\end{tabular}

Table 3

Significance of Regression Coefficients $(N=314)$

\begin{tabular}{|c|c|c|c|c|c|c|}
\hline \multirow[b]{2}{*}{ Model } & \multicolumn{2}{|c|}{$\begin{array}{c}\text { Unstandardized } \\
\text { Coefficients }\end{array}$} & \multicolumn{2}{|c|}{$\begin{array}{l}\text { Standardized } \\
\text { Coefficients }\end{array}$} & \multirow[b]{2}{*}{ Sig. } & \multirow{2}{*}{$\begin{array}{c}\begin{array}{c}\text { Collinearity } \\
\text { Statistics }\end{array} \\
\text { VIF } \\
\end{array}$} \\
\hline & $\mathrm{B}$ & Std. Error & Beta & $\mathrm{t}$ & & \\
\hline 1 (Constant) & 2.450 & 0.243 & & 10.100 & 0.00 & \\
\hline Availability & 0.072 & 0.052 & 0.095 & 1.373 & 0.171 & 2.239 \\
\hline Great value & 0.094 & 0.057 & 0.113 & 1.641 & 0.102 & 2.239 \\
\hline Worth paying & 0.148 & 0.043 & 0.199 & 3.448 & $0.001 *$ & 1.570 \\
\hline Reliability & 0.006 & 0.055 & 0.008 & 0.109 & 0.914 & 2.494 \\
\hline Speed & 0.106 & 0.059 & 0.141 & 1.797 & 0.073 & 2.881 \\
\hline Safety & -0.121 & 0.56 & -.169 & -2.156 & $0.032 *$ & 2.883 \\
\hline Accessibility & 0.133 & 0.065 & 0.175 & 2.028 & $0.043 *$ & 3.490 \\
\hline Continuity & 0.006 & 0.077 & 0.007 & 0.074 & 0.941 & 4.401 \\
\hline Ease of use & 0.081 & 0.065 & 0.104 & 1.250 & 0.212 & 3.224 \\
\hline Encryption & 0.074 & 0.036 & 0.107 & 2.088 & $0.038^{*}$ & 1.224 \\
\hline
\end{tabular}

Note. ${ }^{*} \mathrm{p}<0.05$.

As can be seen in Table 4, the result for coffee shop behavioral loyalty was significant since the sig. level was lower than the critical alpha level of 0.05 . Thus, H1b was supported and it can be concluded that there is a positive impact of Wi-Fi on coffee shop behavioral loyalty. Approximately $39.2 \%$ of the coffee shop behavioral loyalty was explained by the Wi-Fi usage factors from the regression model. 
Nevertheless, not all Wi-Fi usage factors turned out to be significant. Table 5 shows that the results of each factors related to behavioral loyalty separately. Only worth paying $(\mathrm{p}<0.05, \beta=.312, \mathrm{t}=6.45)$, reliability $(\mathrm{p}<0.05, \beta=.123, \mathrm{t}=1.98)$, safety $(\mathrm{p}<$ $0.05, \beta=.152, \mathrm{t}=-2.29)$, accessibility $(\mathrm{p}<0.05, \beta=.222, \mathrm{t}=3.01)$, and encryption $(\mathrm{p}<$ $0.05, \beta=.135, \mathrm{t}=3.37)$ turned out to be significant.

Table 4

Summary of Regression Analysis for Coffee Shop Behavioral Loyalty $(N=314)$

\begin{tabular}{crrrr}
\hline $\mathrm{R}$ & $\mathrm{R}^{2}$ & Adjusted $\mathrm{R}$ & $\mathrm{F}$ & Sig. \\
\hline 0.626 & 0.392 & 0.372 & 19.574 & $0.00^{*}$ \\
\hline Note. $* \mathrm{p}<0.05$. & & & &
\end{tabular}

Table 5

Significance of Regression Coefficients $(N=314)$

\begin{tabular}{|c|c|c|c|c|c|c|}
\hline \multirow[b]{2}{*}{ Model } & \multicolumn{2}{|c|}{$\begin{array}{c}\text { Unstandardized } \\
\text { Coefficients }\end{array}$} & \multicolumn{2}{|c|}{$\begin{array}{c}\text { Standardized } \\
\text { Coefficients }\end{array}$} & \multirow[b]{2}{*}{ Sig. } & \multirow{2}{*}{$\begin{array}{c}\begin{array}{c}\text { Collinearity } \\
\text { Statistics }\end{array} \\
\text { VIF } \\
\end{array}$} \\
\hline & $\mathrm{B}$ & Std. Error & Beta & $\mathrm{t}$ & & \\
\hline 1 (Constant) & 1.121 & 0.273 & & 4.113 & 0.00 & \\
\hline Availability & -0.012 & 0.059 & -0.014 & -0.205 & 0.838 & 2.239 \\
\hline Great value & 0.019 & 0.064 & 0.020 & 0.296 & 0.768 & 2.239 \\
\hline Worth paying & 0.312 & 0.048 & 0.362 & 6.459 & $0.000^{*}$ & 1.570 \\
\hline Reliability & 0.123 & 0.062 & 0.140 & 1.986 & $0.048^{*}$ & 2.494 \\
\hline Speed & 0.152 & 0.066 & 0.174 & 2.294 & $0.022 *$ & 2.881 \\
\hline Safety & -0.223 & 0.063 & -0.268 & -3.527 & $0.000^{*}$ & 2.883 \\
\hline Accessibility & 0.222 & 0.073 & 0.252 & 3.015 & $0.003 *$ & 3.490 \\
\hline Continuity & -0.064 & 0.087 & -0.069 & -0.739 & 0.460 & 4.401 \\
\hline Ease of use & 0.001 & 0.073 & 0.001 & 0.014 & 0.989 & 3.224 \\
\hline Encryption & 0.135 & 0.040 & 0.167 & 3.376 & $0.001 *$ & 1.224 \\
\hline
\end{tabular}


The second hypothesis was formulated to find out the effect of Wi-Fi service on fast-food restaurant's loyalty as following:

H2: Wi-Fi service will have a positive impact on fast-food restaurant's loyalty.

H2a: Wi-Fi service will have a positive impact on fast-food restaurant's attitudinal loyalty.

H2b: Wi-Fi service will have a positive impact on fast-food restaurant's behavioral loyalty.

As can be seen in table 6 , the result for fast-food restaurant attitudinal loyalty was significant since the sig. level is lower than the critical alpha level of 0.05 . Thus, $\mathrm{H} 2 \mathrm{a}$ was supported and it can be concluded that there is a positive impact of Wi-Fi on fastfood restaurant's attitudinal loyalty. Approximately $26.7 \%$ of the fast-food attitudinal loyalty was explained by the Wi-Fi usage factors from the regression model.

Nevertheless, not all Wi-Fi usage factors turned out to be significant. Table 7 shows that the results of each factors related to attitudinal loyalty separately. Only Availability $(\mathrm{p}<0.05, \beta=.176, \mathrm{t}=3.24)$ and ease of using $(\mathrm{p}<0.05, \beta=.158, \mathrm{t}=2.08)$ turned out to be significant.

Table 6

Summary of Regression Analysis for Fast-Food Attitudinal Loyalty ( $N=314)$

\begin{tabular}{|c|c|c|c|c|}
\hline $\mathrm{R}$ & $\mathrm{R}^{2}$ & Adjusted R & $\mathrm{F}$ & Sig. \\
\hline 0.517 & 0.267 & 0.243 & 11.044 & 0.00 * \\
\hline
\end{tabular}

Note. $* \mathrm{p}<0.05$. 
Table 7

Significance of Regression Coefficients $(N=314)$

\begin{tabular}{|c|c|c|c|c|c|c|}
\hline \multirow[b]{2}{*}{ Model } & \multicolumn{2}{|c|}{$\begin{array}{c}\text { Unstandardized } \\
\text { Coefficients }\end{array}$} & \multicolumn{2}{|c|}{$\begin{array}{l}\text { Standardized } \\
\text { Coefficients }\end{array}$} & \multirow[b]{2}{*}{ Sig. } & \multirow{2}{*}{$\begin{array}{c}\begin{array}{c}\text { Collinearity } \\
\text { Statistics }\end{array} \\
\text { VIF }\end{array}$} \\
\hline & $\mathrm{B}$ & Std. Error & Beta & $\mathrm{t}$ & & \\
\hline 1 (Constant) & 2.532 & 0.229 & & 11.049 & 0.00 & \\
\hline Availability & 0.176 & 0.054 & 0.241 & 3.244 & $0.001 *$ & 2.284 \\
\hline Great value & -0.056 & 0.071 & -0.069 & -0.781 & 0.436 & 3.222 \\
\hline Worth paying & 0.095 & 0.056 & 0.111 & 1.705 & 0.089 & 1.757 \\
\hline Reliability & 0.074 & 0.072 & 0.090 & 1.029 & 0.304 & 3.191 \\
\hline Speed & -0.024 & 0.078 & -0.029 & -0.304 & 0.761 & 3.873 \\
\hline Safety & 0.024 & 0.069 & 0.031 & 0.345 & 0.730 & 3.265 \\
\hline Accessibility & 0.074 & 0.084 & 0.089 & 0.892 & 0.373 & 4.107 \\
\hline Continuity & -0.031 & 0.089 & -0.038 & -0.353 & 0.725 & 4.727 \\
\hline Ease of use & 0.158 & 0.076 & 0.197 & 2.084 & $0.038^{*}$ & 3.711 \\
\hline Encryption & 0.013 & 0.042 & 0.016 & 0.302 & 0.763 & 1.234 \\
\hline
\end{tabular}

As can be seen in Table 8, the result for fast-food restaurant behavioral loyalty was significant since the sig. level is lower than the critical alpha level of 0.05 . Thus, $\mathrm{H} 2 \mathrm{~b}$ was supported and it can be concluded that there is a positive impact of Wi-Fi on fastfood restaurant's behavioral loyalty. Approximately $32.1 \%$ of the fast-food behavioral loyalty was explained by the Wi-Fi usage factors from the regression model.

Nevertheless, not all Wi-Fi usage factors turned out to be significant. Table 9 shows that the results of each factors related to behavioral loyalty separately. Only worth paying $(\mathrm{p}<0.05, \beta=.249, \mathrm{t}=4.67)$, accessibility $(\mathrm{p}<0.05, \beta=.203, \mathrm{t}=2.54)$, and encryption $(\mathrm{p}<0.05, \beta=.091, \mathrm{t}=2.27)$ turned out to be significant. 
Table 8

Summary of Regression Analysis for Fast-Food Behavioral Loyalty $(N=314)$

\begin{tabular}{crrrr}
\hline $\mathrm{R}$ & $\mathrm{R}^{2}$ & Adjusted $\mathrm{R}$ & $\mathrm{F}$ & \multicolumn{2}{c}{ Sig. } \\
\hline 0.566 & & & & \\
\hline Note. ${ }^{*} \mathrm{p}<0.05$. & 0.321 & 0.298 & 14.312 & $0.00^{*}$ \\
\hline
\end{tabular}

Table 9

Significance of Regression Coefficients $(N=314)$

\begin{tabular}{|c|c|c|c|c|c|c|}
\hline \multirow[b]{2}{*}{ Model } & \multicolumn{2}{|c|}{$\begin{array}{l}\text { Unstandardized } \\
\text { Coefficients }\end{array}$} & \multicolumn{2}{|c|}{$\begin{array}{c}\text { Standardized } \\
\text { Coefficients }\end{array}$} & \multirow[b]{2}{*}{ Sig. } & \multirow{2}{*}{$\begin{array}{c}\begin{array}{c}\text { Collinearity } \\
\text { Statistics }\end{array} \\
\text { VIF }\end{array}$} \\
\hline & $\mathrm{B}$ & Std. Error & Beta & $\mathrm{t}$ & & \\
\hline 1 (Constant) & 1.154 & 0.219 & & 5.267 & 0.00 & \\
\hline Availability & 0.022 & 0.052 & 0.031 & 0.433 & 0.666 & 2.284 \\
\hline Great value & -0.073 & 0.068 & -0.091 & -1.070 & 0.286 & 3.222 \\
\hline Worth paying & 0.249 & 0.053 & 0.294 & 4.677 & $0.000^{*}$ & 1.757 \\
\hline Reliability & 0.030 & 0.069 & 0.036 & 0.427 & 0.670 & 3.191 \\
\hline Speed & 0.014 & 0.074 & 0.018 & 0.195 & 0.845 & 3.873 \\
\hline Safety & -0.040 & 0.066 & -0.052 & -0.607 & 0.544 & 3.265 \\
\hline Accessibility & 0.203 & 0.080 & 0.244 & 2.540 & $0.012 *$ & 4.107 \\
\hline Continuity & 0.095 & 0.085 & 0.116 & 1.123 & 0.263 & 4.727 \\
\hline Ease of use & -0.006 & 0.072 & -0.007 & -0.080 & 0.936 & 3.711 \\
\hline Encryption & 0.091 & 0.040 & 0.119 & 2.272 & $0.024^{*}$ & 1.234 \\
\hline
\end{tabular}

The third hypothesis was formulated to find out the effect of Wi-Fi service on casual-dining restaurant's loyalty as following:

H3 : Wi-Fi service will have a positive impact on casual-dining restaurant's loyalty.

H3a : Wi-Fi service will have a positive impact on casual-dining restaurant's 
attitudinal loyalty.

H3b : Wi-Fi service will have a positive impact on casual-dining restaurant's behavioral loyalty.

As can be seen in Table 10, the result for casual-dining restaurant attitudinal loyalty was significant since the sig. level was lower than the critical alpha level of 0.05 . Thus, H3a was supported and it can be concluded that there is a positive impact of Wi-Fi on casual-dining restaurant's attitudinal loyalty. Approximately $35.1 \%$ of the casualdining restaurant attitudinal loyalty was explained by the Wi-Fi usage factors from the regression model.

Nevertheless, not all Wi-Fi usage factors turned out to be significant. Table 11 shows that the results of each factors related to attitudinal loyalty separately. Only great value $(\mathrm{p}<0.05, \beta=.154, \mathrm{t}=2.18)$ and accessibility $(\mathrm{p}<0.05, \beta=.253, \mathrm{t}=2.76)$ turned out to be significant.

Table 10

Summary of Regression Analysis for Casual-dining Attitudinal Loyalty ( $N=314)$

\begin{tabular}{crrrr}
\hline $\mathrm{R}$ & $\mathrm{R}^{2}$ & Adjusted $\mathrm{R}$ & $\mathrm{F}$ & Sig. \\
\hline 0.593 & & & & \\
& 0.358 & 0.337 & 16.889 & $0.00^{*}$ \\
\hline Note. ${ }^{*} \mathrm{p}<0.05$. & & & &
\end{tabular}

Table 11

Significance of Regression Coefficients ( $N=314)$

\begin{tabular}{|c|c|c|c|c|c|c|}
\hline \multirow[b]{2}{*}{ Model } & \multicolumn{2}{|c|}{$\begin{array}{c}\text { Unstandardized } \\
\text { Coefficients }\end{array}$} & \multicolumn{2}{|c|}{$\begin{array}{l}\text { Standardized } \\
\text { Coefficients }\end{array}$} & \multirow[b]{2}{*}{ Sig. } & \multirow{2}{*}{$\begin{array}{c}\begin{array}{c}\text { Collinearity } \\
\text { Statistics }\end{array} \\
\text { VIF } \\
\end{array}$} \\
\hline & $\mathrm{B}$ & Std. Error & Beta & $\mathrm{t}$ & & \\
\hline 1 (Constant) & 1.990 & 0.216 & & 9.221 & 0.00 & \\
\hline
\end{tabular}




\begin{tabular}{lllllll}
\hline Availability & 0.047 & 0.027 & 0.092 & 1.721 & 0.086 & 1.358 \\
Great value & 0.131 & 0.060 & 0.154 & 2.184 & $0.030^{*}$ & 2.346 \\
Worth paying & 0.042 & 0.054 & 0.047 & 0.793 & 0.429 & 1.667 \\
Reliability & -0.159 & 0.087 & -0.181 & -1.832 & 0.068 & 4.582 \\
Speed & 0.083 & 0.077 & 0.098 & 1.080 & 0.281 & 3.850 \\
Safety & -0.042 & 0.075 & -0.051 & -0.553 & 0.581 & 4.094 \\
Accessibility & 0.220 & 0.079 & 0.253 & 2.766 & $0.006 *$ & 3.944 \\
Continuity & 0.159 & 0.088 & 0.188 & 1.810 & 0.071 & 5.119 \\
Ease of use & 0.037 & 0.066 & 0.044 & 0.559 & 0.577 & 2.983 \\
Encryption & 0.061 & 0.040 & 0.079 & 1.505 & 0.133 & 1.299 \\
\hline Note. ${ }^{*} \mathrm{p}<0.05$. & & & & & &
\end{tabular}

As can be seen in Table 12, the result for casual-dining restaurant behavioral loyalty was significant $(\mathrm{p}<0.05)$. Thus, H3b was supported and it can be concluded that there is a positive impact of Wi-Fi on casual-dining restaurant's behavioral loyalty.

Approximately $38 \%$ of the casual-dining restaurant behavioral loyalty was explained by the Wi-Fi usage factors from the regression model.

Nevertheless, not all Wi-Fi usage factors turned out to be significant. Table 13 shows that the results of each factors related to behavioral loyalty separately. Only great value $(\mathrm{p}<0.05, \beta=.163, \mathrm{t}=2.97)$, worth paying $(\mathrm{p}<0.05, \beta=.189, \mathrm{t}=3.86)$, accessibility $(\mathrm{p}<0.05, \beta=.197, \mathrm{t}=2.71)$, and encryption $(\mathrm{p}<0.05, \beta=.073, \mathrm{t}=1.98)$ turned out to be significant.

Table 12

Summary of Regression Analysis for Casual-dining Behavioral Loyalty $(N=314)$

\begin{tabular}{ccccr}
\hline $\mathrm{R}$ & $\mathrm{R}^{2}$ & Adjusted $\mathrm{R}$ & $\mathrm{F}$ & Sig. \\
\hline 0.622 & & & & \\
\hline Note. ${ }^{*} \mathrm{p}<0.05$. & 0.387 & 0.367 & 19.142 & $0.00^{*}$ \\
\hline
\end{tabular}


Table 13

Significance of Regression Coefficients $(N=314)$

\begin{tabular}{|c|c|c|c|c|c|c|}
\hline \multirow[b]{2}{*}{ Model } & \multicolumn{2}{|c|}{$\begin{array}{l}\text { Unstandardized } \\
\text { Coefficients }\end{array}$} & \multicolumn{2}{|c|}{$\begin{array}{l}\text { Standardized } \\
\text { Coefficients }\end{array}$} & \multirow[b]{2}{*}{ Sig. } & \multirow{2}{*}{$\begin{array}{c}\text { Collinearity } \\
\text { Statistics } \\
\text { VIF } \\
\end{array}$} \\
\hline & B & Std. Error & Beta & $\mathrm{t}$ & & \\
\hline 1 (Constant) & 0.811 & 0.197 & & 4.112 & 0.00 & \\
\hline Availability & -0.011 & 0.025 & -0.024 & -0.460 & 0.645 & 1.358 \\
\hline Great value & 0.163 & 0.055 & 0.205 & 2.971 & $0.003 *$ & 2.346 \\
\hline Worth paying & 0.189 & 0.049 & 0.224 & 3.865 & $0.000 *$ & 1.667 \\
\hline Reliability & -0.029 & 0.079 & -0.035 & -0.364 & 0.716 & 4.582 \\
\hline Speed & -0.032 & 0.070 & -0.040 & -0.454 & 0.650 & 3.850 \\
\hline Safety & 0.025 & 0.069 & 0.033 & 0.361 & 0.718 & 4.094 \\
\hline Accessibility & 0.197 & 0.073 & 0.243 & 2.719 & $0.007 *$ & 3.944 \\
\hline Continuity & 0.054 & 0.080 & 0.068 & 0.670 & 0.503 & 5.119 \\
\hline Ease of use & -0.005 & 0.061 & -0.007 & -0.089 & 0.929 & 2.983 \\
\hline Encryption & 0.073 & 0.037 & 0.102 & 1.984 & $0.048 *$ & 1.297 \\
\hline
\end{tabular}

Note. ${ }^{*} \mathrm{p}<.05$.

\section{Summary}

Results indicated that Wi-Fi service factors had an impact on both attitudinal and behavioral loyalty for all three types of restaurants. However, Wi-Fi service was much more important for coffee shop loyalty than fast-food restaurants and casual dining restaurants. 


\section{CHAPTER V \\ DISCUSSION}

\section{Introduction}

This chapter includes discussions about the findings of this study and managerial implications of the findings. Also, this chapter concludes with limitations and recommendations for future research.

\section{Discussion of Results}

This study attempted to test whether Wi-Fi service has a impact on loyalty among different types of restaurants: coffee shops, fast-food restaurants and casual-dining restaurants. Wi-Fi service was categorized into ten usage factors and loyalty was examined from two different perspectives: attitudinal and behavioral. Furthermore, this study classified the restaurants into three different types (coffee shops, fast-food restaurants, and casual-dining restaurants) to see how Wi-Fi service affects customer loyalty differently. Empirical results from this study offer valuable finding with regards to Wi-Fi service and returning customers to the restaurant businesses in the hospitality industry. This study particularly stresses the importance of providing appropriate Wi-Fi service for customers in order to increase strong loyalty in restaurants businesses and hospitality industries.

While all of the three study hypotheses were supported, not all of the Wi-Fi usage factors were significant consistently. First, Wi-Fi service factors turned out to be significant for coffee shop attitudinal and behavioral loyalty. Worth paying, safety, accessibility, and encryption were significant for both attitudinal loyalty and behavioral 
loyalty. Reliability and the speed of Wi-Fi service would further encourage customers to become behaviorally loyal to coffee shops.

Second, Wi-Fi service factors turned out to be significant for fast-food restaurant attitudinal and behavioral loyalty. Availability and ease of use were significant for attitudinal loyalty, while, worth paying, accessibility, and encryption were significant for behavioral loyalty. Customers preferred fast-food restaurants where Wi-Fi service was available and where Wi-Fi service was easy to use, but this did not necessary indicate that they would be behaviorally loyal to that specific fast-food restaurant brand. If the fastfood restaurant did not provide free Wi-Fi service, customers considered it was worth paying for Wi-Fi service. Additionally, accessibility and encryption of Wi-Fi service were more influential in actually visiting the fast-food restaurant.

Lastly, Wi-Fi service factors turned out to be significant for casual dining restaurant attitudinal and behavioral loyalty. Great value and accessibility were significant for attitudinal loyalty and great value, worth paying, accessibility, and encryption were significant for behavioral loyalty. Customers found great value from casual dining restaurants that provide Wi-Fi service and considered the accessibility of Wi-Fi service most important to become both attitudinally and behaviorally loyal to a casual dining restaurant. Customers believed it was worth paying for Wi-Fi service and considered encryption important when they visit casual dining restaurants. Generally, WiFi service factors were more significant for behavioral loyalty than attitudinal loyalty. Worth paying, accessibility, and encryption were significant for behavioral loyalty across all three different types of restaurants, but there did not exist such uniformity for attitudinal loyalty for both coffee shops and casual dining restaurants. Also, Wi-Fi service 
factors were more significant for coffee shop loyalty than fast-food restaurants or casual dining restaurants. It can be assumed that Wi-Fi service plays a more important role for coffee shops than fast-food restaurants and casual dining restaurants. The fact that worth paying was significant for behavioral loyalty for all three restaurants emphasizes that WiFi service plays an important role in increasing restaurant customer loyalty.

\section{Implications for Management}

The findings of this study have practical implications that would be able to assist the management for restaurant businesses. Consequently, Wi-Fi service factors were not consistently significant for the three types of restaurants. Thus, each type of restaurant needs to utilize Wi-Fi service differently towards their customers.

Generally, customers use and prefer Wi-Fi service more in coffee shops. People normally go to coffee shops to spend their leisure or spare time with a cup of coffee. It is more a place to hang out and meet people rather than to take care of a meal or eat food. Eating or having a meal is not the primary reason for visiting a coffee shop, thus many people enjoy spending their times on their mobile devices and laptops while drinking their beverages and talking to others. Just because coffee shops provide Wi-Fi service for their customers, it does not necessarily mean that the service is safe. As people spend more time on devices that connect to Wi-Fi in coffee shops, coffee shops need to pay particularly more attention to providing secure Wi-Fi service. Although costs may be more expensive, coffee shops should connect with specific companies that supply highsecurity Wi-Fi models. It is also highly recommended for coffee shops to include encryption services to improve the quality of Wi-Fi security. 
Customers who dine at fast-food restaurants typically spend less time there than in coffee shops or casual dining restaurants. Thus, security is not as essential and just providing Wi-Fi service can be an attractive point for customers. Most customers are not willing to pay for Wi-Fi service at fast-food restaurants. Thus, a paying option should not be considered. Nowadays, most of the major fast-food restaurant chains provide Wi-Fi service for free. They do not offer any encryption for their customers since customers want to use Wi-Fi as easily as they expect. For these reasons, fast-food restaurants do not need to offer high quality Wi-Fi service and do not have to spend more money to improve their Wi-Fi quality, such as reliability speed and safety.

For casual dining restaurants, Wi-Fi service is able to give more value for customers than fast-food restaurants. Customers generally spend more time at casual restaurants due to longer waiting time and eating time. Customers have more time to use Wi-Fi service and find great value when Wi-Fi service is available. Even though customers spend more time at casual dining restaurants, they prefer Wi-Fi service with easy access. Thus, casual dining restaurants should provide the easy accessibility of WiFi service for their customers, such as offering open access Wi-Fi service. Unlike fastfood restaurants, customers are willing to pay for Wi-Fi service at casual dining restaurants. Thus, just by providing Wi-Fi service for their customers, casual dining restaurants are more likely to obtain competitive advantages. Wi-Fi service is more significant for casual dining restaurant customers than fast-food restaurants. Wi-Fi service can become an attractive point for customers at casual dining restaurants if it is convenient to use. 


\section{Limitations}

As with all research, this study has several limitations. First of all, this study used a non-probability convenience sampling method for data collection, and data was collected only in South Korea. Thus, study findings cannot be generalized. Additionally, using a convenience sampling method may have limited the participants in various demographic groups. More than one-third of the participants of this study were students', so it may be difficult to generalize the results. Study findings cannot be generalized to other types of restaurants, such as fine dining restaurants, luxury, and high-level restaurants as well.

Although it can be assumed from the results of this study that there is a positive relation between Wi-Fi usage factors and a customer's loyalty, R square value of the multiple linear regression performance indicated that a relatively low proportion of variation was explained by the model. The result of the $\mathrm{R}$ square value of each multiple linear regression performances ranged between $26.7 \%$ and $39.2 \%$. Therefore, a higher value of $\mathrm{R}$ square is actually preferable in terms of explaining variability. Customer loyalty is a multifaceted concept where a variety of factors may have an impact on. Thus, there may be additional factors that should have been added to the model that may explain customer loyalty other than the Wi-Fi service factors suggested in this study.

\section{Recommendations for Future Research}

Several recommendations for future study can be suggested. Replication of this study is recommended to generalize study findings, as this is one of the very few empirical studies that attempted to identify the Wi-Fi services effect on customer loyalty 
at restaurants. Including additional factors that may account for Wi-Fi service is strongly recommended.

Future studies should use a larger sample size using a probability random sampling method, including various demographic groups to support the increasing generalizability of the results. Studies should especially attempt to include a wider range of ages and nationalities and examine whether there are any differences between demographic factors.

This study was conducted based on three types of restaurants. It did not cover upscale restaurants and fine dining restaurants. It would be interesting to examine whether Wi-Fi service may be an influential factor in the upper segments of the restaurant industry as well. It would also be interesting to investigate the Wi-Fi impact on other hospitality business areas, such as hotels, airports, and so on. Finally, it would be interesting to investigate the impact of Wi-Fi service factors between domestic customers and international customers. Travelers are expected to show different consumer behaviors, so results are likely to suggest meaningful findings for restaurant management.

\section{Summary}

Consequently, the hypotheses for this study were supported. However, not all of the Wi-Fi factors turned out to have significant impact consistently on customer loyalty for three types of restaurants (coffee shops, fast-food restaurants ,and casual dining restaurants). Replication of this study with a random sample and a bigger sample size is recommended. Future studies should also include other factors that may impact customer loyalty. 


\section{REFERENCES}

Arnold, M., \& Reynolds, K. (2003). Hedonic shopping motivations. Journal of Retailing, 79(2), 77-95.

Backman, S. J. (1988). The utility of selected personal and marketing characteristics in explaining consumer loyalty to selected recreation services. Retrieved from Dissertation Abstracts International. Unpublished $\mathrm{PhD}$ dissertation, Texas A\&M University, College Station, TX.

Balachandran, A., Voelker, G. M., \& Bahl, P. (2005). Wireless hotspots: Current challenges and future directions. Mobile Networks and Application, 10(3), 265 274.

Baloglu, S. (2002). Dimensions of customer loyalty: separating friends from well-wishers. Cornell Hotel and Restaurant Administration Quarterly, 43(1), 47-59.

Belk, R. W. (1975). Situational variables and consumer behavior. Journal of Consumer Research, Vol. 2, No. 3, 157-164.

Berezina, K., Bilgihan, A., Cobanoglu, C., \& Nusair, K. (2012). The impact of Wi-Fi service in restaurants on customers' likelihood of return to a restaurant. Journal of Foodservice Business Research, 15(1), 285-299.

Berry, L. L., Parasuraman, A., \& Zeithaml, V. A. (1991). Refinement and reassessment of the SERVQUAL scale. Journal of retailing, 67(4), 420-450.

Brodie, R., Davis, R., Lindgree, A., \& Oliver, M. (2000). Pluralism in contemporary marketing practices. International Journal of Bank Marketing, 294- 308.

Bradwell, J. (2005). Wi-Fi radio characteristics and cost of WLAN implementation. Retrieved from http://www.connect802.com/download/techpubs/2005/commercial_radios_E05 3-15.pdf.

Bolton, R. (1998). A dynamic model of the duration of the customer's relationship with a continuous service provider: The role of satisfaction. Marketing Science, 7(1), 45-65.

Bowen, J. T., \& Chen, S. L. (2001). The relationship between customer loyalty and customer satisfaction. International Journal of Contemporary Hospitality Management, 13(5), 213-217.

Birgelen, M., Lemmink, J., Odekerken, S., Ruyter, K., \& Wetzels, M. (2000). Moments of sorrow and joy: an empirical assessment of the complementary value of critical incidents in understanding customer service evaluations. European Journal of Marketing, 34 (1-2), 107-25. 
Busler, M., \& Till, Brian, D. (2000). The match-up hypothesis: physical attractiveness, expertise, and the role of fit on brand attitude, purchase intent and brand beliefs. Journal of Advertising, 24(3), 1-13.

Buhalis, D. (1998). Strategic use of information technologies in the tourism industry. Tourism Management, 19(5), 409-421.

Cheng, S. (2011). Comparisons of competing models between attitudinal loyalty and behavioral loyalty. International Journal of Business and Social Science, 2(10), 149-166.

Dachin, A., \& Mitchell, A. (1996). The assessment of alternative measures of consumer expertise. Journal of Consumer Research, 23(1), 219-39.

Davis, F. D. (1989). Perceived usefulness, perceived ease of use, and user acceptance of information technology.MIS Quarterly, 13(3), 319-339.

Davis, F. D., Bagozzi, R. P., \& Warshaw, P. R. (1989). User acceptance of computer technology: A comparison of two theoretical models. Management Science, 35(8) 982-1003.

Danny, K. (2015). Hyatt the largest hotelier to offer all guests free WiFi. Travel Weekly, V 74. Retrieved from http://www.travelweekly.com/Travel-News/Hotel News/Hyatt-thelargest-hotelier-to-offer-all-guests-free-WiFi

Day, G. S. (1969). A two-dimensional concept of brand loyalty. Journal of Advertising Research, Vol. 9, No.3.

Demarez, L., Evens, T., Schuurman, D., \& Verleye, G. (2010). Forecasting broadband Internet adoption on trains in Belgium. Telematics and Informatics, 27, 10-20.

Dicenzo, T. (2012). Pinkbery serves up Wi-Fi guest services with a side of rewards. Retrieved from http://www.airtightnetworks.com/fileadmin/pdf/case_study/Pinkberry-Case Study.pdf.

Evanschitzky, H., \& Wunderlich, M. (2006). An Examination of Moderator Effects in the Four Stage Loyalty Model. Journal of Service Research, 8(4).330-345.

Giering, A ., \& Homburg, C. (2001). Personal characteristics as moderators of the relationship between customer satisfaction and loyalty: an empirical analysis. Psychology and marketing, 18(1), 43-66.

Gill, T., \& Saad, G. (2000). Applications of evolutionary psychology in marketing. Psychology and Marketing, 17 (12), 1005-35. 
Hair, J, F., Anderson, R. E., Tatham, R. L., \& Black, W. C. (1998). Multivariate data analysis. Retrieved from Delhi, India: Pearson Education.

Han, H., Back, K., \& Barrett, B. (2009). Consumption emotion measurement development: a full-service restaurant setting. The Service Industries Journal, $30(2)$.

Hassine, T. (2006). Overview of WLAN security. Retrieved from http://www.tml.tkk.fi/Publications/C/22/papers/Hassinen_final.pdf.

Heide, J. B., \& Weiss, A. M. (1995). Vendor consideration and switching behavior for buyer in high-technology markets. Journal of Marketing, 59, 30-43.

Yusio, N., \& Ting, L. (2011). Free WiFi as strategic competitive advantage for fast-food outlet inthe knowledge era. American Journal of Economics and Business Administration, 3(2) 352-357.

Jacoby, J., \& Chestnut, R. (1978). Brand loyalty measurement and management. John Wiley and Sons, New York.

Jang, D., \& Mattila, A. (2005). An examination of restaurant loyalty programs: what kind of rewards do customers prefer? International Journal of Contemporary Hospitality Management, 17(5), 402-408.

Keller, K. L., \& Kotler, P. (2011). Marketing management (14Ed.). New Jersey.

Kumar, V., Shah. D., \& Venkatesan, R. (2006). Managing retailer profitability-one customer at a time. Journal of Retailing, 82(4), 277-294.

Natasa, C. (2014). Restaurants Discuss Wi-Fi Access Models at Murtec. Hospitality Technology. Retrieved from http://hospitalitytechnology.edgl.com/news/Restaurants-Discuss-Wi-Fi Access-Models-at-MURTEC91907.

Means, P. (2013). Three key consideration when deploying WiFi in restaurants. National Service Center, 1-3.

Morgan, R., \& Hunt, S. D. (1994). The commitment-trust theory of relationship marketing. Journal of Marketing, Vol. 58, No. 3, 20-38.

Oliver, R. L. (1997). Satisfaction: A behavioral perspective on the consumer. Retrieved from New York, NY: McGraw-Hill.

Oliver, R. L. (1999). Whence Consumer Loyalty? Journal of marketing, 63, 33-44.

Olson, J., \& Jacoby, J. (1971). A construct validation study of brand loyalty. American Psychological Association, Miami, Fl. 
Onguardonline, G. (2011). Tips for using public Wi-Fi networks. Retrieved from http://www.onguardonline.gov/articles/0014-tips-using-public-wi-fi-networks.

Park, J. Y., \& Jang, S. Y. (2014). Revisit and satiation patterns: Are your restaurant customers satiated? International Journal of Hospitality Management, 38, 20-29.

Petrick, J. F. (2005). Reoperationalising the loyalty framework. Tourism and Hospitality Research, Vol. 5, No. 3, 199-212.

Porter, M. E. (1985). Competitive Advantage. New York, NY: Free Press.

Ramirez, R. F. (2010). Individuals behavior regarding open Wi-Fi networks. Thesis. Rochester Institute of Technology, 1-62.

Raphaelle, L, P., Gilles, L., \& Eric, L. (2005). Repeat purchasing of new automobiles by older consumers: empirical evidence and interpretations. Journal of Marketing, 69, 98-113.

Rice, K. (2013). Airlines work to improve speed and availability of in-flight Wi-Fi. Travel Weekly, vol. 72 issue 10.

Smithers, R. (2007). McDonald's to offer free Wi-Fi in restaurants. Retrieved from http://www.guardian.co.uk/technology/2007/oct/06/internet.

Swanson, E. B. (1987). Information channel disposition and use. Decision Sciences, 18(1), 131-145.

Wicker, A. W. (1969). The relationship between attitudes and behavior as a function of specificity of the attitude object. Unpublished manuscript, University of Wisconsin, Milwaukee.

Ullah, I. (2012). A study and analysis of public WiFi. Department of Compute and Information Science. 


\section{APPENDIX: A QUESTIONNAIRE}

Wi-Fi Service Value Survey

1. Do you currently use Wi-Fi? (If you check yes, start next question.)

$\square$ Yes $\quad \square$ No

2. To what extent do you agree about Wi-Fi in the following?

\begin{tabular}{|c|c|c|c|c|c|c|}
\hline $\mathbf{1}$ & $\mathbf{2}$ & $\mathbf{3}$ & $\mathbf{4}$ & $\mathbf{5}$ & $\mathbf{6}$ & $\mathbf{7}$ \\
\hline $\begin{array}{c}\text { Strongly } \\
\text { Disagree }\end{array}$ & Disagree & $\begin{array}{c}\text { Somewhat } \\
\text { Disagree }\end{array}$ & $\begin{array}{c}\text { Neither } \\
\text { Disagree Nor } \\
\text { Agree }\end{array}$ & $\begin{array}{c}\text { Somewhat } \\
\text { Agree }\end{array}$ & Agree & $\begin{array}{c}\text { Strongly } \\
\text { Agree }\end{array}$ \\
\hline
\end{tabular}

\begin{tabular}{|c|c|c|c|c|c|c|c|}
\hline & 1 & 2 & 3 & 4 & 5 & 6 & 7 \\
\hline $\begin{array}{l}\text { Wi-Fi in Coffee Shops } \\
\text { I prefer coffee shops where Wi-Fi service is available. }\end{array}$ & & & & & & & \\
\hline Wi-Fi provides great value in coffee shops. & & & & & & & \\
\hline It is worth paying for Wi-Fi access in coffee shops. & & & & & & & \\
\hline I consider the reliability of Wi-Fi important in coffee shops. & & & & & & & \\
\hline I consider the speed of Wi-Fi most important in coffee shops. & & & & & & & \\
\hline I consider the safety of Wi-Fi most important in coffee shops. & & & & & & & \\
\hline $\begin{array}{l}\text { I consider the accessibility of Wi-Fi most important in coffee } \\
\text { shops. }\end{array}$ & & & & & & & \\
\hline $\begin{array}{l}\text { I consider the continuity of Wi-Fi most important in coffee } \\
\text { shops. }\end{array}$ & & & & & & & \\
\hline $\begin{array}{l}\text { I consider the ease of using of Wi-Fi most important in coffee } \\
\text { shops }\end{array}$ & & & & & & & \\
\hline I use encryption while using Wi-Fi in coffee shops. & & & & & & & \\
\hline $\begin{array}{l}\text { Wi-Fi in Fast-Food Restaurants } \\
\text { I prefer fast-food restaurants that provide Wi-Fi service. }\end{array}$ & & & & & & & \\
\hline Wi-Fi provides great value in fast-food restaurants. & & & & & & & \\
\hline It is worth paying for Wi-Fi access in fast-food restaurants. & & & & & & & \\
\hline I consider the reliability of Wi-Fi important in fast-food & & & & & & & \\
\hline I consider the speed of Wi-Fi most important in fast-food & & & & & & & \\
\hline I consider the safety of Wi-Fi most important in fast-food & & & & & & & \\
\hline I consider the accessibility of Wi-Fi most important in fast-food & & & & & & & \\
\hline I consider the continuity of Wi-Fi most important in fast-food & & & & & & & \\
\hline I consider the ease of using of Wi-Fi most important in fast-food & & & & & & & \\
\hline I use encryption while using Wi-Fi in fast-food restaurants. & & & & & & & \\
\hline $\begin{array}{l}\text { Wi-Fi in Casual Dining Restaurants } \\
\text { I prefer casual dining restaurants that provide Wi-Fi service. }\end{array}$ & & & & & & & \\
\hline Wi-Fi provides great value in casual dining restaurants. & & & & & & & \\
\hline
\end{tabular}




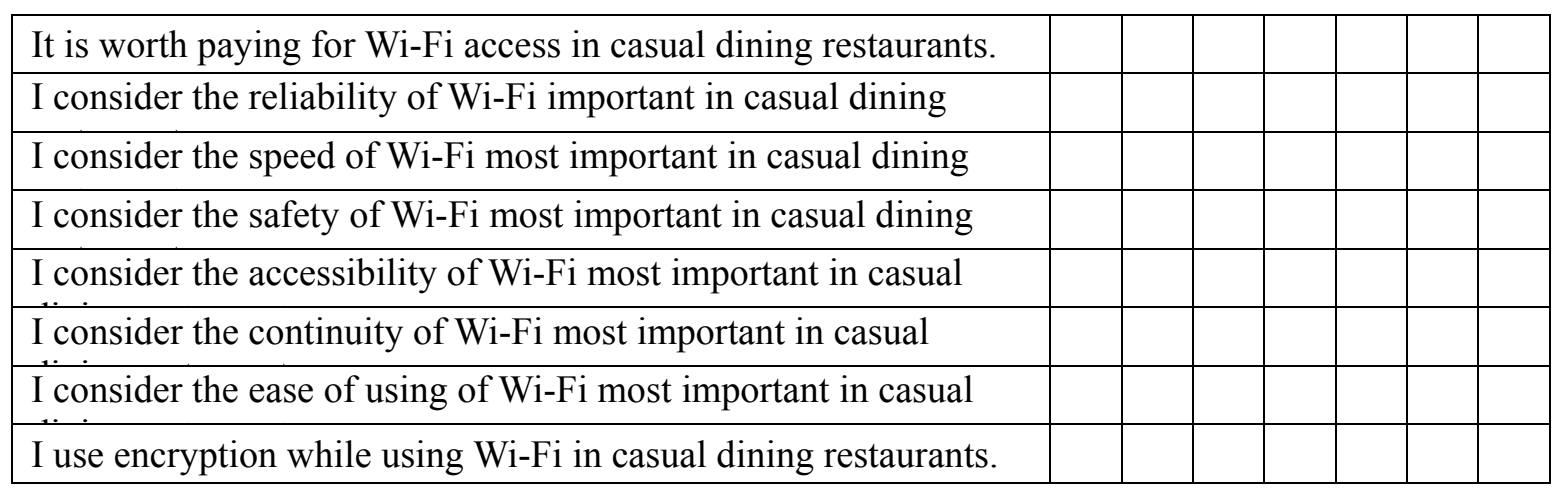

3. To what extent do you agree that Wi-Fi affects your deciding in the following at your favorite coffee shops or restaurants? (Please write down a number from 1 to 7.$)$

\begin{tabular}{|c|c|c|c|c|c|c|}
\hline $\mathbf{1}$ & $\mathbf{2}$ & $\mathbf{3}$ & $\mathbf{4}$ & $\mathbf{5}$ & $\mathbf{6}$ & $\mathbf{7}$ \\
\hline $\begin{array}{c}\text { Strongly } \\
\text { Disagree }\end{array}$ & Disagree & $\begin{array}{c}\text { Somewhat } \\
\text { Disagree }\end{array}$ & $\begin{array}{c}\text { Neither } \\
\text { Disagree } \\
\text { Nor Agree }\end{array}$ & $\begin{array}{c}\text { Somewhat } \\
\text { Agree }\end{array}$ & Agree & $\begin{array}{c}\text { Strongly } \\
\text { Agree }\end{array}$ \\
\hline
\end{tabular}

\begin{tabular}{|l|l|l|l|}
\hline & $\begin{array}{c}\text { Coffee } \\
\text { Shops }\end{array}$ & $\begin{array}{c}\text { Fast-Food } \\
\text { Restaurants }\end{array}$ & $\begin{array}{c}\text { Casual } \\
\text { dining } \\
\text { Restaurants }\end{array}$ \\
\hline $\begin{array}{l}\text { Attitudinal loyalty } \\
\text { Wi-Fi makes me feel good. }\end{array}$ & & & \\
\hline Wi-Fi provides hedonic value for me. & & & \\
\hline Wi-Fi provides very consistent service. & & & \\
\hline Wi-Fi gives me satisfaction. & & & \\
\hline $\begin{array}{l}\text { Behavior loyalty } \\
\text { I make purchase because of Wi-Fi. }\end{array}$ & & & \\
\hline I revisit because of Wi-Fi. & & & \\
\hline I am willing to spend more because of Wi-Fi. & & & \\
\hline I recommend to friends and family because of Wi-Fi. & & & \\
\hline I maintain a relationship because of Wi-Fi. & & & \\
\hline
\end{tabular}

\section{Demographics Information}

4. What is your age?
$\square 18-24$
$\square 25-34$
$\square 35-44$
$\square 45-54$
$\square 55$ or older

5. What is your gender?
$\square$ Female
$\square$ Male

6. What is the highest level of education you have completed?
$\square$ High school
$\square$ College
$\square$ Bachelor's degree

$\square$ Master’s degree $\square$ Doctoral degree $\square$ Professional degree $\quad \square$ other 
7. Which category best describes your race?

$\square$ Asian or Pacific Islander

$\square$ Caucasian or White $\square$ Black or African American

$\square$ Hispanic or Latino

$\square$ American Indian or Alaska Native $\square$ Multiracial

$\square$ Other:

8. What is your current marital status?

$\square$ Divorced $\quad \square$ Living with another $\quad \square$ Married $\quad \square$ Separated
$\square$ Single

9. What is your occupation?

10. Do you currently live in the US? If not indicate.

$\square$ Yes $\quad \square \mathrm{NO}:$

11. What is your current household income in U.S dollars?

$$
\begin{array}{ll}
\square \text { Under } \$ 10,000 \quad \square \$ 10,000-\$ 19,999 & \square \$ 20,000-\$ 29,999 \\
\square \$ 30,000-39,999 & \square \$ 40,000-\$ 49,999 \\
\square \$ 75,000-99,999 & \square \text { Over } \$ 100,000
\end{array}
$$

